\title{
A Framework for e-Library Services to Support the e-Learning Environment In a Secondary School: A Case Study
}

\author{
Rana A. Abuzaid \\ Ph.D. Student \\ University of Malaya \\ Malaysia \\ Diljit Singh \\ Associate Professor \\ University of Malaya \\ Malaysia
}

\begin{abstract}
This paper proposes an ICT-based framework that incorporates e-library services into the e-learning environment. There has been wide recognition that the integration of elibrary services within e-learning environments is lacking. The literature suggests that there is no formal collaboration between teachers, students and librarians in the course of the proposing, acquiring and utilising of e-library resources. The proposed framework defines different scenarios, roles and learning cycles that support different interactions within the e-learning process. The system is expected to provide greater opportunities to fulfil students' needs with less time and effort.
\end{abstract}

\section{Introduction}

In the past, traditional libraries were major sources of information. In the early 1990s, the digital library was an experimental project. Today, the digital library is an issue of practical implementation. In this implementation, the main issues are integration and interoperability (Limb, 2004, p.65).

New technologies have shifted traditional library services to "electronic access to a myriad of databases, proliferation of Internet sites, and patron expectations of speedy service" (Burke, 2003, p.66). E-learning systems have been introduced with the emergence of and developments in information technology (IT). However, most e-learning systems focus on allowing students to access and use official educational content, with less attention being paid to involving the e-library services in support of the educational process. According to Lance (2003), schools with stronger school library programs average 10-20\% higher test scores than those without. Recently, there has been wide recognition of the importance of the integration of elibrary services into the learning environment. As determined by Abuzaid (2005), e-library services are expected to provide greater added value to the e-learning process. Though this incorporation may add an extra load on students and schools, but new information communication technologies (ICT) can ease this concern. Lamb and Callison (2005, p. 29) believe that building an e-library will improve the experience of online students, and it is important that the students have the information skills needed to be successful in the e-learning 
environment. One of these information skills is the ability to access knowledge, which needs to be done through a framework to make it easier and more efficient with the school's curriculum. The aim of this paper is to put forward a conceptual framework for e-school libraries to play a major role as part of the e-learning environment.

\section{Background}

According to American Library Association, Human Resource Development and Recruitment, Careers in Libraries, one of the librarian's duties is to "collaborate with other educators" and "introduce students to the latest e- resources" (ALA,2005). Along with International Federation Library Association, School Library Manifesto which states, "it has been demonstrated that when librarians and teachers work together, students achieve higher levels of literacy, reading, learning, problem-solving and information and communication technology skills" (IFLA, 2002).

The librarians have to expand their traditional roles and work more closely (collaboratively) with teachers and students to provide proper tools, materials, resources and instructional services (Bargellini \& Bordoni, 2001). Mardis (2006) summarized that although "leading publications do contain a number of articles emphasizing the importance of collaboration in general, less than $5 \%$ of articles published between 1998 and 2004 were dedicated to any aspect of the librarian working with science teachers or students". According to Kuhlthau (1997), creating a learning environment in an e-library is based on the concept of acting and reflecting, and it is important to work collaboratively with teachers to afford quality elibrary services.

The inappropriate subject matter is more symptomatic of a lack of dialogue between librarians and educators (Mardis, 2005). According to Oldenetttel, Malachinski \& Reil (2003), the e-library was originally not designed to be part of the learning management system, and file structures and formats of the documents in e-library were not appropriate to learning aspects; they are more to publication aspects. Attwell (2003) stated that there is a lack of quality learning materials. As said by Budhu (2005), it is time consuming and frustrating to find quality information and whether these e-resources can meet the needs of educators and learners is questionable.

Grimes \& Boening (2001), in a case study of students and faculty in English classes at a community college, found that students went directly to Web resources without consulting librarians. The study concluded that there was a gap between the library resources expected to be used and the student actual usage.

This background emphasizes the need for our framework involving students, teachers and librarians to formally collaborate to provide relevant e-resources to support curriculum.

\section{Al Bayan Secondary School}

The proposed framework is based on a case study at the Al-Bayan Model Girl's Secondary School in Jeddah, Saudi Arabia. The study sample comprised 470 students, which is the whole secondary school population. E-learning was implemented in the school in 2003. The 
study will assess the impact of the framework as a system on learning and collaboration in the school e-learning environment.

\section{E-learning Environment}

Computer-supported educational systems have been developed as one inspiration to apply the capabilities of computers to different education fields, and encourage the activities of students (Watanabe, 2003). This technology is briefly described as e-learning, and refers to various learning scenarios where technology plays a major role in the delivery of the educational content. Since its inception, the e-learning approach has witnessed many transformations. The advances in ICT and the growth in the use of the Internet have massively reshaped the e-learning concept. Communications through the Internet have enabled greater interaction between students, teachers, librarians, and the educational content. It also enabled learning materials to be accessed from anywhere through the web or the Intranet.

In addition to face-to-face dialog, teachers and students can also communicate with each other using e-mail, chat or discussion forums. This very intercommunication-rich environment has helped to make students into active seekers rather than passive recipients of knowledge. According to Comerchero (2006), e-learning, helps students incorporate self-motivation, communication, and efficiency into their learning. However, in order to be successful, any elearning system must satisfy availability, reliability, performance, scalability and extensibility requirements in a cost-effective way (Mgd, 2003, p.5).

\section{Our framework}

\section{Conceptual framework}

Setting up a framework for the incorporation of e-library services within e-learning environments has been a lacking feature. Though school libraries have existed for a long time but their role has always been regarded as optional. Schools need a defined framework in which its teachers, students and librarians can formally collaborate to provide relevant e-resources to support curriculum. In order to be successful, the framework has to be based on close cooperation between librarian, students and teachers. We propose that not only e-resources requested by librarians and teachers must be considered, but students are also included into this process. Therefore, the e-resource acquisition, quality assessment and management are planned and coordinated in a collaborative way. Through this, e-library services become a major part of the realization of the e-learning process. This collaborative e-resources management also helps in continuous collaborative e-resource filtering and refining, based on students' feedback.

As learning become a social process and is mostly realized through collaboration, our framework suggests grouping the different e-learning stakeholders into three categories namely: Student, Librarian and Teacher. They collaborate through many cycles as defined in the following scenario.

\section{Collaborative Scenario for the Proposed Framework}

The proposed framework defines a set of roles and learning cycles that support the aims of e-library-supported e-learning in formal collaborative way. 
First, the student initiates a request for an information resource. Upon the endorsement or rejection of the student's request, the student receives either a notification of e-resource acquisition or a notification about similar e-resources. The links of similar e-resources are sent to the requester consequently. In addition, the student can search and browses e-resource on different subjects, and rates their appropriateness.

Secondly, the librarian receives and reviews the students' requests list. If there are similar e-resources already available, she rejects the request and sends feedback to the student as notification that there are similar e-resources available. Links to similar e-resources are included in the notification. If not available, the librarian temporarily adds requested e-resource details and seeks teacher's endorsement to consider adding the requested e-resource to the e-library collection. If the teacher does not make her endorsement within three days, the librarian approves the e-resources and makes it viewable by students.

Thirdly, the teacher browses the e-resources list forwarded by the librarian. She can review and endorse any of the listed e-resources that will be activated later by the librarian. If she considers any e-resource as inappropriate or it is not feasible to be added, she posts a rejection comment and sends it back to the librarian. Therefore, the librarian adds another e-resource details and the cycle is restarted by sending the newly added e-resource to the teacher for endorsement. The cycle is repeated until the appropriate e-resource is successfully endorsed and made viewable to the students. Later, the librarian can monitor the available e-resources used by students and teachers.

This framework is shown in Fig. 1.

\section{Continuous evaluation of appropriateness for e-library collection}

Systematic evaluating during usage helps improve the quality of e-resources in various contexts, by proactively offering guidance on how to provide and how to select best-matching learning materials (Althoff \& Pfahl, 2003, p.269-270).

The Digital Library for Earth System Education (DLESE) Collection Committee has established seven criteria by which educational e-resources must be evaluated for inclusion in the reviewed collection (Kastens, 2005). We adopt these criteria for our e-library collection, viz.:

- Scientific accuracy.

- Importance or significance.

- Pedagogical effectiveness.

- Well- documented.

- Ease of use for students.

- Power to inspire or motivate students.

- Robustness as e- resources. 


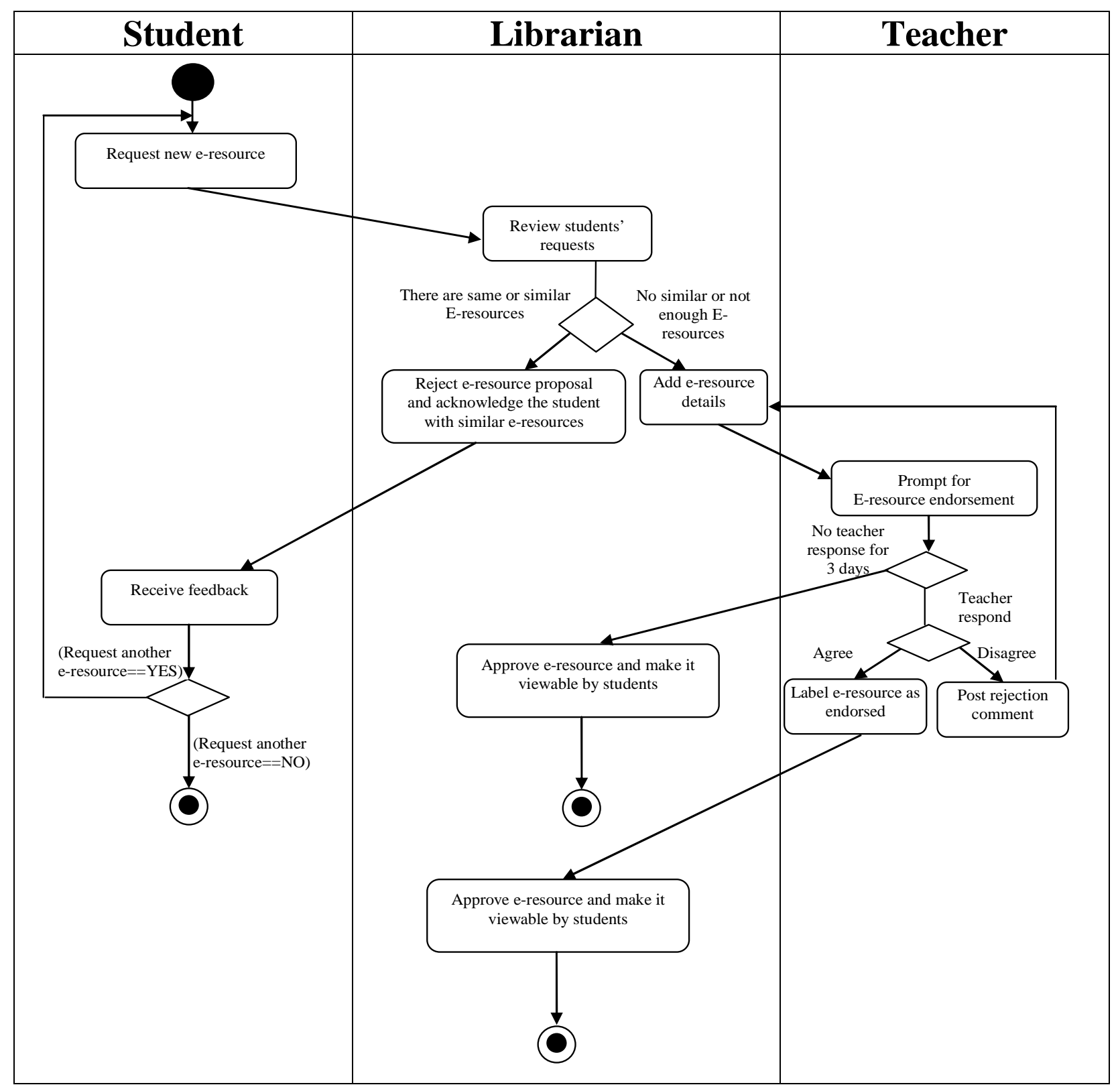

Figure 1. UML, Swim Lane, Outline of a conceptual framework for e-library services supporting an e-learning environment

\section{Conclusion}

In summary, the library services aspect that supports the e-learning environment has generally been lacking. Thus, the incorporation of e-library services within an e-learning environment must take place, and schools need a clear conceptual framework in which its students, teachers and librarians can collaborate to provide relevant e-resources to support lifelong learning. Through this framework presented above, the e-library can play a major role in the e-learning environment. 


\section{References}

Abuzaid, R. A.(2005). Preparation and training of Employees in Information Technology Field in the University Libraries and Information Centers in the Kingdom of Saudi Arabia. Masters dissertation, Jeddah: King Abdul Aziz University.

ALA. (2005) Human Resource Development and Recruitment: Career in Libraries. American Library Association , Retrieved June 2, 2006, http://www.ala.org/ala/hrdr/careersinlibraries/childrenyouth.htm.

Althoff, K-D,\& Pfahl, D. (2003). Making Software Engineering Competence Development Sustained Through Systematic Experience Management. In A. Aurum, R.Jeffery, C.Wohlin \& M. Handzic (Eds.), Managing Software Engineering Knowledge (pp.269-275). Berlin,Germany: Springer. (Arabic).

Attwell, G.(2003). Knowledge and E-Learning . The Wales- Wide Web, Retrieved November 5, 2006, from http:// www.knownet.com/writing/weblogs/Graham_Attwell/entries/

Bargellini,M.L., and Bordoni, L. (2001) The role of the library in new learning scenario, The Electronic Library, 19 (3) , 153-157.

Budhu, M. (2005). Engineering Education Using Resources In Digital. Libraries, 6th International Conference on Information Technology Based Higher Education and Training, Juan Dolio, Dominican Republic: ITHET, IEEE.

Burke, M. (2003). Access Services in the 21th Century. In A. Hanson \& B. L. Levin (Eds.), Building a Virtual Library (pp. 66-77). United Kingdom: Information Sciences Publishing.

Comerchero, M.(2006). What is e-learning. In E-Learning Concepts and Techniques (pp.1-12). Pennsylvania, USA: Bloomsburg University of Pennsylvania, Retrieved October 13, 2006, http://iit.bloomu.edu/Spring2006_eBook_files/chapter1.htm\#h1_1.

Grimes, D. J., and C. H. Boening. (2001). Worries with the Web. College \& Research Libraries ,62(1) ,11-23. WilsonWeb Library Literature Full-Text Database. Retrieved June 17, 2004, http://vnweb.hwwilsonweb.com.proxy.ulib.iupui.edu

IFLA / UNESCO (2002). School Library Manifesto: The School Library in Teaching and Learning for All. International Federation of Library Association and Institutions, Retrieved May 2, 2006, from http:// www.ifla.org.

Kastens, K. (2005). The DLESE Community Review System: Gathering, Aggregating, and Disseminating User Feedback about the Effectiveness of Web- based Educational Resources, Journal of Geoscience Eduction,53(1), 37-43.

Kuhlthau, Carol C. (1997). Learning in Digital Libraries: An Information Search Process Approach. Library Trends, 45 (4), 5-15.

Lamb,A. \& Callison, D. (2005). Online Learning and Virtual Schools. Key Words In Instruction, XXI (9), 29-35.

Lance, Keith C. (2003) 5 Roles for empowering school librarians, Library Research Service, Colorado state Library: University of Denver.

Limb, P. (2004). Digital Dilemmas and Solution. Oxford, England : Chandos Publishing.

Mgd (2003) Al-Bayan School Network Design . Jeddah, Saudi Arabia : Dar Almarekh.

Mardis, M. A. (2005). The relationship between SLMCs and science achievement in Michigan middle schools. Doctoral dissertation, Department of Educational Leadership, Eastern Michigan University: Ypsilanti. 
Mardis, M. A. (2006). Science teacher and school library media specialist roles: Mutually reinforcing perspectives as defined by national guidelines. In M. Orey, V. J. McClendon \& R. M. Branch (Eds.), Educational and Media Technology Yearbook 2006. Westport, Conn.: Libraries Unlimited.

Watanabe, T.(2003). Computer Supported Educational Environment. IEEE . 0-7803-7661-7/03/\$17.0002003 IEEE, 280-290.

\section{Author Note:}

Rana A. Abuzaid is a Ph.D. student at University of Malaya, Kuala Lumpur. She received a Master in Information Technology from the University of Malaya, and M.A. in Library and Information Sciences from King Abdul Aziz University, Saudi Arabia. Her primary research is in the area of Training and Developing Librarians for the information technology era. Her research interests E-Library, E-Learning, Computer Supported Collaborative Work, and Knowledge Management.

\section{Author Note:}

Diljit Singh holds a B.Sc. from the University of Malaya, Kuala Lumpur, and an M.S. and Ph.D. from Florida State University, USA. He taught in two schools, and worked at the state and federal levels of the Ministry of Education Malaysia before joining the university. Diljit is currently an Associate Professor at the Faculty of Computer Science and Information Technology, University of Malaya, in Kuala Lumpur. He is also currently the Vice President, and a past Director (Asia), of the International Association of School Librarianship. 